\title{
Raised serum hyaluronate levels in scleroderma: an effect of growth factor induced activation of connective tissue cells?
}

\author{
ANNA ENGSTRÖM-LAURENT,${ }^{12}$ NILS FELTELIUS,${ }^{2}$ ROGER HÄLLGREN ${ }^{2}$ \\ AND $\AA K E$ W A STESON \\ From the ${ }^{I}$ Department of Medical and Physiological Chemistry, the Biomedical Center, Uppsala University; \\ the ${ }^{2}$ Department of Internal Medicine, University Hospital, Uppsala, Sweden; and the ${ }^{3}$ Clinical Research \\ Center, University of Linköping, Sweden
}

SUMmARY The circulating levels of hyaluronate were determined in 36 patients with $\vec{\triangleright}$ scleroderma and in 36 control subjects matched for age and sex. The mean serum hyaluronate concentration in patients with progressive systemic sclerosis $(n=25)$ was $131 \pm 67(\mathrm{SD}) \mu \mathrm{g} / \mathrm{l}$ and significantly greater $(\mathrm{p}<0 \cdot 001)$ than that of the controls (mean level $49 \pm 21(\mathrm{SD}) \mu \mathrm{g} / \mathrm{l}) \stackrel{\mathbb{D}}{\mathbb{D}}$ Hyaluronate levels in patients with localised scleroderma $(n=4)$ were $141 \pm 47(\mathrm{SEM}) \mu \mathrm{g} / \mathrm{l}$ and in patients with scleroderma-associated overlap syndromes $(n=7) 202 \pm 54(\mathrm{SEM}) \mu \mathrm{g} / \mathrm{l}$. The increase in serum hyaluronate probably reflected an enhanced synthesis or outflow of hyaluronate frome the connective tissue, or both; it could not be explained by affection of the liver, which is the catabolic site of hyaluronate. The hyaluronate values were not related to certain serologigapo indicators of inflammatory activity or to the extent of the skin lesions or the severity of intermaib organ manifestations. A positive correlation was noted between circulating platelet counts antos hyaluronate levels $(\mathrm{p}<0.001)$. Plasma $\beta$-thromboglobulin was measured in 15 of the patients with systemic sclerosis and found to correlate positively with platelet counts. Raised levels of: $\beta$-thromboglobulin were associated with the highest hyaluronate values. Platelet-derived growth factor, which stimulates connective tissue cells and is stored in the $\alpha$-granules of platelets together with $\beta$-thromboglobulin, was shown to enhance hyaluronate synthesis in fibroblast cultures. The 3 results suggest an involvement in scleroderma of connective tissue activating substances release from platelets.

Key words: hyaluronic acid, systemic sclerosis, platelets, fibroblasts, platelet-derived growthọ factor.

Systemic scleroderma is an inflammatory connective tissue disease with unpredictable but often unfavourable prognosis. Immunological aberrations ${ }^{1-4}$ and affection of the microvascular system ${ }^{5}$ have been detected, but the aetiology remains unknown. A striking manifestation in scleroderma is the replacement of subcutaneous fat by abnormal connective tissue and accumulation of collagen. ${ }^{6}$ Uitto et al. reported an excess glycosaminoglycan content

Accepted for publication 5 March 1985.

Correspondence to $\mathrm{Dr}$ Anna Engström-Laurent, Section of Rheumatology, Dept of Internal Medicine, University Hospital, S-751 85 Uppsala, Sweden. in the skin of scleroderma patients, ${ }^{7}$ and Fleisch majer and Perlish found an increase of dermatan. sulphate. ${ }^{\gamma}$ Increased urinary excretion of glycosaminoñ glycans in scleroderma has also been reported possibly reflecting the severity of the disease. $\stackrel{N}{\circ}$ Cultured skin fibroblasts from patients with sclerow derma were recently shown to synthesise considerably more hyaluronate than normal skin fibroblasts. ${ }^{10}$ if Hyaluronate seems to enter the circulation via the lymph $^{12}$ and is rapidly eliminated by the hepaticen+ pathway. ${ }^{1314}$ Although the resulting concentrationso of circulating hyaluronate are normally quite low the development of a new sensitive assay for 
hyaluronate ${ }^{15}$ has enabled its determination not only in plasma or serum but in various biological fluids and tissue samples. ${ }^{15-18}$ In the present work this method was applied to the determination of circulating hyaluronate levels in scleroderma, and to a study of whether raised levels correlated with the severity or progress of the disease.

\section{Patients and methods}

\section{PATIENT DATA}

Thirty-six inpatients with sclerodermatous skin changes were included in the study. They had a mean age of 52 years and a mean disease duration of 7.5 years. Twenty-five patients qualified for the diagnosis of progressive systemic sclerosis (PSS). ${ }^{19}$ Four patients suffered from morphea, i.e., a purely dermatological affection with no systemic component. Seven patients possessed clinical hallmarks common to PSS but showed high antibody titres against extractable nuclear antigen and met the clinical criteria for mixed connective tissue disease (MCTD) established by Sharp. ${ }^{20}$ At the time of blood collection 11 of the patients with PSS were treated with cyclofenil $100-500 \mathrm{mg} /$ day, alone or in combination with prednisolone $(n=5) 2 \cdot 5-10 \mathrm{mg} /$ day. Two patients received penicillamine $500 \mathrm{mg} /$ day, and another two received prednisolone $5-7.5 \mathrm{mg} /$ day as the only drug. Ten patients were without drug treatment, as were all patients with morphea. One patient with MCTD was treated with prednisolone $7.5 \mathrm{mg} /$ day.

\section{ANALYTICAL METHODS}

Hyaluronate was determined according to the principles previously outlined ${ }^{15}$ and recently adapted for measurements of serum samples. ${ }^{18}$ In short, protein with specific affinity for hyaluronate was prepared from cartilage by affinity chromatography and labelled with ${ }^{125} \mathrm{I}$. The radioactive protein was incubated with varying amounts of free hyaluronic acid and a fixed amount bound to a Sepharose gel. The protein was allowed to partition between free and bound polysaccharide. The amount of radioactivity pelleted with the gel is a function of the amount of free hyaluronate in the sytem. $500 \mu \mathrm{l}$ of the test sample was incubated with the following reagents for $20 \mathrm{~h}$ at $4^{\circ} \mathrm{C}$ during slow rotation: (1) 400 $\mu l$ of $1.5 \mathrm{M}$ sodium chloride, $0.025 \mathrm{M}$ phosphate buffer, $\mathrm{pH} 7 \cdot 0$, containing $33 \mathrm{mM}$ ethylenediaminetetra-acetic acid (EDTA) (Merck, Darmstadt, FRG), $3 \mathrm{mg} / 1$ soybean trypsin inhibitor (Worthington, Freehold, NJ), $1 \mathrm{mM}$ iodoacetic acid (Sigma, St Louis, MO), $3 \mathrm{mM}$ phenylmethylsulphonyl fluoride (Sigma), $17 \mathrm{mM}$ benzamidine (Sigma), $3 \mathrm{mg} / \mathrm{l}$ pepstatin A (Sigma), and $0.33 \mathrm{M} \varepsilon$-amino- $n$-caproic acid (Sigma); (2) $0.5 \mu$ l of hyaluronate-substituted gel $^{14}$ suspended in $400 \mu \mathrm{l}$ of $0.55 \mathrm{M}$ sodium chloride and $0.05 \mathrm{M}$ sodium borate, $\mathrm{pH} 7 \cdot 0$; (3) $100 \mu \mathrm{l}$ of ${ }^{125} \mathrm{I}$ labelled cartilage protein in $4 \mathrm{M}$ guanidinium chloride, ${ }^{14}$ about $20000 \mathrm{cpm}$. After the incubation the gel was collected by centrifugation and washed twice. Standard curves for hyaluronate were obtained by the use of sodium hyaluronate (Healon) dissolved in saline containing bovine serum albumin (Sigma).

The acute phase plasma proteins, haptoglobin and orosomucoid, were measured by nephelometry at the Department of Clinical Chemistry and the serum levels of $\operatorname{IgG}, \operatorname{IgA}$, and $\operatorname{IgM}$ by immunodiffusion at the Department of Clinical Immunology, University Hospital, Uppsala. White blood cells were measured by means of a Coulter counter and platelets by means of a Thrombocounter (Coulter Electronics Ltd, Great Britain). $\beta$-Thromboglobulin was assayed by a commercial kit (Amersham International, Amersham, UK). The normal mean plasma $\beta$-thromboglobulin value in our laboratory is $24 \mu \mathrm{g} / \mathrm{l}$, two SD ranges $\leq 10-50 \mu \mathrm{g} / \mathrm{l}$. Blood samples were also subjected to the following analyses: alanine aminotransferase, aspartate aminotransferase, bilirubin, and creatinine by means of a multichannel analyser (Greiner Electronics, Switzerland) with original reagents.

\section{CLINICAL FUNCTIONAL TESTS}

Pulmonary function tests were performed at the Department of Clinical Physiology, University Hospital, Uppsala and included determinations of total lung capacity, residual volume, vital capacity, and forced expiratory volume. Oesophageal function was assessed by radiography of the oesophagus in the supine position and by cineradiography. Renal function was evaluated by creatinine and $\left[{ }^{51} \mathrm{Cr}\right]$ EDTA clearance measurements.

IN-VITRO EXPERIMENTS

Human normal foreskin fibroblasts (AG 1523, obtained from the Human Genetic Mutant Cell Repository, Institute for Medical Research, Camden, New Jersey) were plated in Eagle's minimal essential medium at a split ratio of 1:10 in Nunc $35 \mathrm{~mm}$ dishes (A/S Nunc, Roskilde, Denmark). After four days of incubation the medium was removed, and the cultures were incubated for two days in serum-free MCDB 105 medium $^{21} 22$; at this stage the cultures had not yet reached confluency. Pure platelet-derived growth factor (PDGF; available in our laboratory ${ }^{23}$ ) or epidermal growth factor (EGF; Collaborative Research Incorporated, Waltham, Massachusetts) was then added at $10 \mu \mathrm{g} / \mathrm{l}$, and the incubation was prolonged for up to $30 \mathrm{~h}$. 
The medium was harvested, and the remaining cell layer was digested with $1.0 \mathrm{ml}$ of trypsin $(50 \mathrm{mg} / \mathrm{l}$ in phosphate-buffered saline). The medium and trypsin fractions were assayed for hyaluronic acid in the presence of protease inhibitors as described previously. ${ }^{14} 17$

Statistical analyses were performed according to Student's $t$ test.

\section{Results}

SERUM HYALURONATE AND OTHER

LABORATORY FINDINGS

Table 1 lists the serum hyaluronate levels in patients with PSS, morphea, and MCTD. In PSS patients the average hyaluronate concentration was about three times higher than in age and sex matched healthy controls $(p<0 \cdot 001)$. Raised serum hyaluronate levels of approximately the same magnitude were also observed in patients with morphea. The greatest increases were found in patients with overlap syndrome (MCTD). No relationship between serum hyaluronate and sex or age or duration of the disease was apparent. We observed no apparent differences between hyaluronate values in PSS patients subdivided according to therapy.

Comparison of serum hyaluronate levels with other laboratory variables (Table 2) showed no relation with either acute phase plasma proteins or with the serum immunoglobulin pattern $(p>0.05)$. A positive correlation was observed between serum hyaluronate levels and blood platelet counts in patients with PSS $(r=0.50, p<0.01)$; this remained

Table 1 Serum hyaluronate ${ }^{*}$ in patients with sclerodermatous skin diseases

\begin{tabular}{lrc}
\hline Diagnosis & $n$ & $\begin{array}{l}\text { Serum hyaluronate } \\
(\mu g / l)\end{array}$ \\
\hline PSS & 25 & $131(26-294)$ \\
Morphea & 4 & $141(57-300)$ \\
MCTD & 7 & $202(58-405)$ \\
Controls & 36 & $49(19-82)$ \\
\hline
\end{tabular}

- Mean values with actual ranges. when patients with morphea and MCTD were included in the statistical analysis $(r=0.55, p<0.001)$ ? (Fig. 1). No relationship was seen between serum $\vec{F}$ hyaluronate levels and polymorphonuclear or monocyte counts.

When it became apparent that a relationship $\overline{\overline{\bar{N}}}$ existed between platelet counts and serum hyaluron- $-\frac{\Phi}{\sigma}$ ate levels we performed concomitant measure- 0 ments of plasma $\beta$-thromboglobulin, serum hyalur-ळ onate, and platelet counts in 15 of our patients with $\vec{\circ}$ PSS. Their mean $\beta$-thromboglobulin level was $108-$ $\mu \mathrm{g} / \mathrm{l}$ (range 32-299 $\mu \mathrm{g} / \mathrm{l}$ ). Eight of the patients had $\vec{\omega}$ $\beta$-thromboglobulin levels exceeding $50 \mu \mathrm{g} / \mathrm{l}$, i.e., the upper normal range. Their mean serum hyaluronateō value was $173 \mu \mathrm{g} / \mathrm{l}$, whereas the mean hyaluronate value was $109 \mu \mathrm{g} / \mathrm{l}$ in those PSS patients who hadio normal $\beta$-thromboglobulin levels. There was a significant relationship between the $\beta$-thrombo- $\vec{A}$ globulin values and the platelet counts $(r=0.51$, 을 $\mathrm{p}<0 \cdot 05)$.

SERUM HYALURONATE AND CLINICAL F I N D IN GS

The progression of the skin disease was not related to the hyaluronate levels. All patients were studiegd for internal manifestations of scleroderma. In the PSS group severe or moderate impairment of the lung function was observed in nine cases and minor impairment in three cases. Three patients with MCTD had moderate to minor lung affection. Severe oesophageal dysfunction was found in $14 \%$ patients with PSS and two patients with MCTD;迅 moderate oesophageal dysfunction was seen in five $\overrightarrow{\vec{A}}$ patients with PSS and two patients with MCTD. 3 Signs of renal affection were noted in two cases with PSS. No overall correlation was evident between? circulating hyaluronate levels and the degree of affection of the above organs $(p>0 \cdot 05)$. Allo patients with MCTD suffered from arthritis. Only윽 three patients with PSS had significant complaints: related to major joints, these patients did not show응 prominent hyaluronate increases. One patient had slightly increased serum levels of $S$-aspartate amino-은 transferase (ASAT) and $S$-alanine aminotransferase $>$ (ALAT) as signs of liver affection.

Table 2 Laboratory findings ${ }^{*}$ in patients with PSS, morphea, or MCTD

\begin{tabular}{|c|c|c|c|c|c|}
\hline Diagnosis & $\begin{array}{l}\text { Haptoglobin } \\
(g / l)\end{array}$ & $\begin{array}{l}\text { Orosomucoid } \\
(\mathrm{g} / \mathrm{l})\end{array}$ & $\begin{array}{l}I g G \\
(g / l)\end{array}$ & $\begin{array}{l}\operatorname{Ig} A \\
(g / l)\end{array}$ & $\begin{array}{l}\lg M \\
(g / l)\end{array}$ \\
\hline PSS & $1 \cdot 6 \pm 0 \cdot 2$ & $0 \cdot 9 \pm 0 \cdot 1$ & $13 \cdot 5 \pm 0 \cdot 6$ & $2 \cdot 5 \pm 0 \cdot 3$ & $1 \cdot 2 \pm 0 \cdot 2$ \\
\hline Morphea & $2 \cdot 3 \pm 0 \cdot 4$ & $0.9 \pm 0 \cdot 2$ & $11 \cdot 2 \pm 0 \cdot 8$ & $2.4 \pm 0.9$ & $1 \cdot 0 \pm 0 \cdot 2$ \\
\hline MCTD & $2 \cdot 6 \pm 0 \cdot 8$ & $1 \cdot 0 \pm 0 \cdot 2$ & $20 \cdot 0 \pm 1 \cdot 8$ & $2 \cdot 2 \pm 0 \cdot 5$ & $0.8 \pm 0.2$ \\
\hline Reference ranges & $0 \cdot 3-2 \cdot 0$ & $0 \cdot 4-1 \cdot 2$ & $8 \cdot 2-19 \cdot 9$ & $0 \cdot 7-3 \cdot 2$ & $0 \cdot 3-2 \cdot 2$ \\
\hline
\end{tabular}




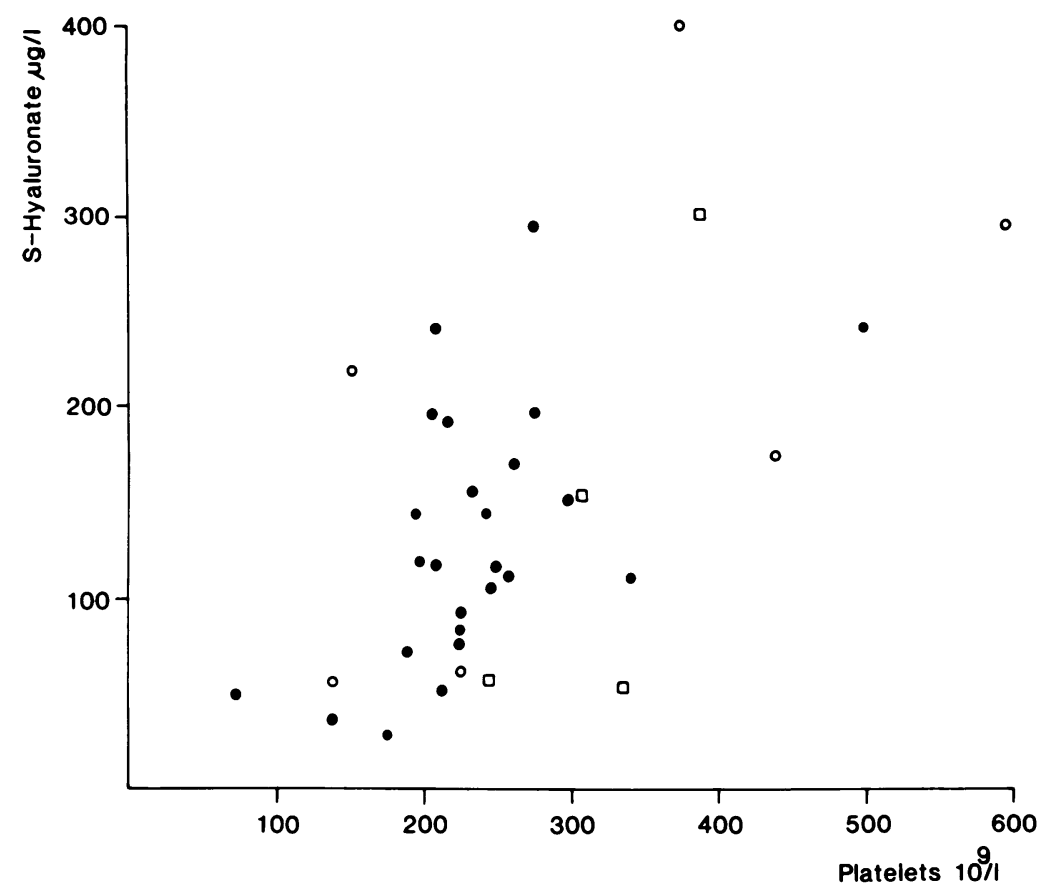

Fig. 1 Relationship between serum levels of hyaluronate and blood platelet counts, in patients with PSS (O), MCTD (O), and morphea ( $\square$ ).

I N-VITRO EXPERIMENTS

The clinical evidence for increased platelet activity in scleroderma and the fact that platelets contain the growth factors PDGF and EGF acting on mesenchymal cells induced us to test whether these factors influenced the synthesis of hyaluronate.

Incubation of human foreskin fibroblasts with PDGF or EGF in a completely synthetic medium caused an increase in hyaluronate accumulation both in the medium (3.7-5.2-fold stimulation) and in the cell layer (trypsin fraction; 1.6-1.7-fold stimulation) (Table 3). Since there was an increase in the total amount of hyaluronate in the cultures, the observed effect was ascribed to an increase in the

Table 3 Determination of hyaluronic acid in fibroblast cultures incubated in the presence or absence of PDGF and EGF for 30 hours

\begin{tabular}{|c|c|c|c|}
\hline Condition & Compartment & $\begin{array}{l}\text { ng hyaluronatel } \\
\text { dish }\end{array}$ & $\begin{array}{l}\text { Fold } \\
\text { stimulation }\end{array}$ \\
\hline \multirow{2}{*}{ No addition } & Medium & $123 \cdot 4$ & 1 \\
\hline & Cell layer & $129 \cdot 1$ & 1 \\
\hline \multirow{2}{*}{ PDGF, $10 \mu \mathrm{g} / \mathrm{l}$} & Medium & $657 \cdot 0$ & $5 \cdot 2$ \\
\hline & Cell layer & $221 \cdot 6$ & $1 \cdot 7$ \\
\hline \multirow{2}{*}{$\mathrm{EGF}, 10 \mu \mathrm{g} / 1$} & Medium & $459 \cdot 0$ & $3 \cdot 7$ \\
\hline & Cell layer & $206 \cdot 7$ & $1 \cdot 6$ \\
\hline
\end{tabular}

Mean of duplicate determinations on duplicate dishes. net synthesis of hyaluronic acid in the presence of the growth factors, rather than to a shift in distribution of hyaluronic acid between different compartments of the culture. Determination of hyaluronate after shorter periods of stimulation showed an increase in hyaluronic acid production at $20 \mathrm{~h}$ but not at $8 \mathrm{~h}$ (Fig. 2).

\section{Discussion}

The present findings of raised serum levels of hyaluronate in progressive systemic scleroderma are in accordance with previous ideas of disturbed glycosaminoglycan metabolism in this disease. ${ }^{7-10}$ However, the significance of such a postulated disturbance, at least when estimated by serum hyaluronate measurements, seems less evident for the disease process. Thus we were unable to link serum hyaluronate values to the severity of internal organ manifestations or to the intensity of the inflammatory process as reflected by serum concentrations of acute phase plasma proteins or immunoglobulins. If it is assumed that raised hyaluronate levels in the circulation of scleroderma patients could originate from certain affected organs, then one should particularly consider the sclerodermatous skin as a possible source, since raised serum hyaluronate levels were observed also in patients with the morphea type of scleroderma who 


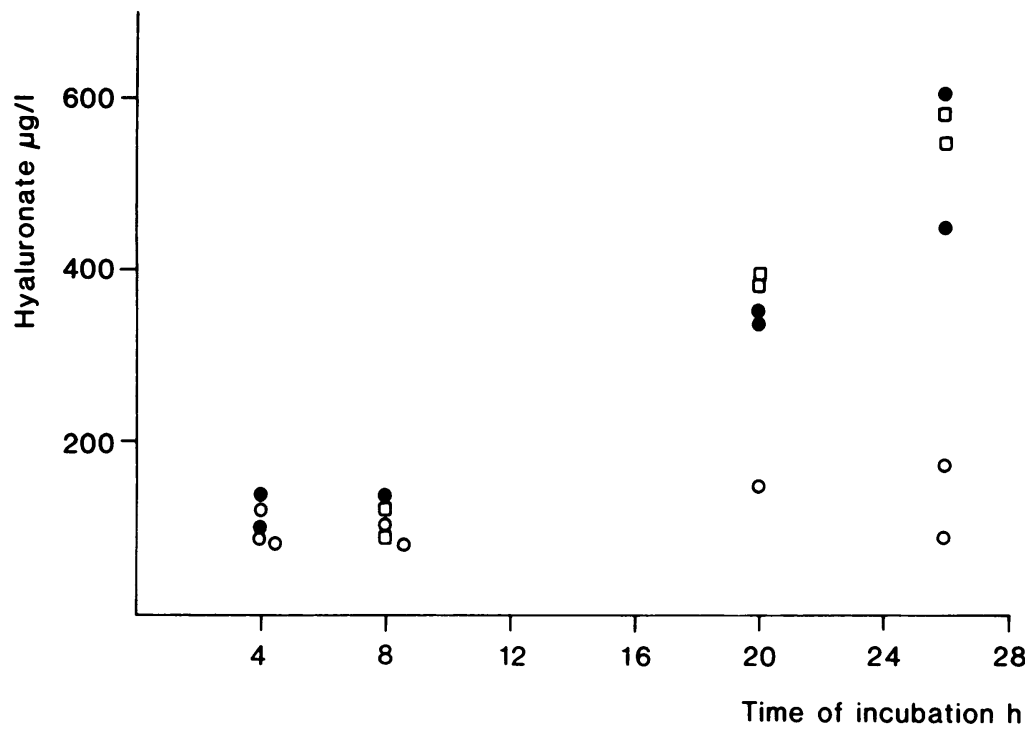

Fig. 2 The amount of hyaluronate in the medium during incubation of foreskin fibroblasts for various times with $P D G F 10$ $\mu g / l(O)$, with EGF $10 \mu g / l(\square)$, and in the absence of additives $(O)$ lacked other organ manifestations. However, no relationship existed in PSS or morphea between serum hyaluronate and the extent of the sclerosis in the skin. Experimental studies indicate that some circulating hyaluronate could arise from the joint and more specifically the synovial fluid, which is very rich in this polysaccharide. ${ }^{24}$ Increased synovial production of hyaluronate is likely in inflammatory arthritides owing to the greatly increased volumes of synovial fluid found in these conditions. We have therefore attributed to the inflamed synovial tissue a critical role for the increased blood concentrations recently detected in rheumatoid arthritis. ${ }^{25}$ An enhanced outflow from the joint cavity might be one mechanism behind the raised serum hyaluronate values found in our scleroderma patients with overlap syndrome, since all suffered from joint complaints and various degrees of arthritis. However, it seems less likely that such a mechanism could provide a general explanation for the raised serum levels in scleroderma, since only three patients with systemic sclerosis had apparent joint involvement.

The mechanisms regulating the in-vivo synthesis of hyaluronate are unknown, but studies in vitro indicate that certain inflammatory mediators like prostaglandin $\mathrm{E}$ and interferon may stimulate fibroblasts to an enhanced hyaluronate production. ${ }^{26}$ Such mediators might also be operative in inflammatory conditions like scleroderma. The observation that the blood platelet counts in our scleroderma patients were positively correlated to their serum hyaluronate values prompted us to examine the effect on hyaluronate synthesis of platelet-derived growth factor (PDGF), a defined growth factor from $\stackrel{ }{-}$ platelets. $^{27}$ Since according to a recent repogt $\vec{\odot}$ epidermal growth factor EGF may also be a normale platelet constituent, ${ }^{28}$ the latter was also included the study. An in-vitro system was selected (cultured? human skin fibroblasts) that may reflect the activities of the same category of cells as that affected ing scleroderma, i.e., cells of the connective tissue type. $\frac{\mathrm{D}}{\mathrm{D}}$

Both growth factors, in pure form and in the absence of non-defined additives, markedly enhanced $\frac{\hat{3}}{3}$ the production of hyaluronate. Similar findings have previously been made with the so-called connective tissue activating peptides. ${ }^{29}{ }^{30}$ PDGF is normally stored in the platelet $\alpha$-granules ${ }^{27}$ and would have to $\frac{0}{2}$ be released from this site in order to reach putative target cells. There is as yet no completely reliable 3 . technique for measuring the concentrations of PDGF in plasma, and therefore we have not attempted to $₹$ determine this component in the plasma of ouro scleroderma patients. Recently, however, raised levels of circulating $\beta$-thromboglobulin, anothero polypeptide of the platelet $\alpha$-granules, ${ }^{31}$ were re- $N$ ported in this disease, indicating in-vivo activation? of platelets and increased release of platelet granule $N$ constituents. ${ }^{32}$ Under conditions of selective release ${ }_{\mathrm{W}}$ PDGF is accompanied by $\beta$-thromboglobulin, ${ }^{33}$ suggesting that increased circulating levels of PDGF also may be found in scleroderma. Analysis of $\frac{c}{\mathscr{C}}$ $\beta$-thromboglobulin in 15 of our patients confirmed $\stackrel{\rho}{+}$ that there are raised levels. The values were also 0 positively correlated with the platelet counts. It is tempting to suggest that both the proliferation of ${ }_{\Omega}^{\mathbb{Q}}$ 
connective tissue and the increased level of serum hyaluronate in scleroderma are due to a pathological release of PDGF, a growth factor known specifically to activate mesenchymal cells. ${ }^{27}$

Other factors which might influence the circulating hyaluronate levels in scleroderma include impaired hepatic elimination of polysaccharide and abnormal metabolism due to pharmacological therapy. It has been demonstrated in vivo that the uptake and degradation of hyaluronate occur in the liver sinusoids $^{13}{ }^{34}$; experiments in vitro have shown that this occurs in the endothelial cell fraction. ${ }^{35} 36$ Observations of very high serum values of hyaluronate in cirrhotic patients further emphasise the central role of the liver in hyaluronate metabolism. ${ }^{37}$ Our patients with scleroderma had no laboratory signs of liver disease, but this does not rule out the theoretical possibility of an affection of the liver endothelial cells in this disease. A number of our patients with PSS were treated with low dosages of corticosteroids. Such treatment but at higher dosages reduces pathologically increased serum hyaluronate levels, at least in patients with active rheumatoid arthritis. ${ }^{25}$

In conclusion this study has shown that there are raised levels of hyaluronate in serum from patients with scleroderma and suggests that this may be due to abnormal stimulation by connective tissue activating substances from platelets.

Supported by grants from the Swedish Medical Research Council, Gustaf V 80 Year Fund. the Swedish Association against Rheumatism, the Medical Faculty of Uppsala, and Signe and Reinhold Sunds' Foundation.

\section{References}

1 Chaves F C, Rodrigo F G, Franco M L, Esteves J. Systemic sclerosis associated with auto-immune haemolytic anaemia. $\mathrm{Br} \mathrm{J}$ Dermatol 1970; 82: 298-302.

2 Murray-Lyon I M, Thompson R P H, Ansell I D, Williams R. Scleroderma and primary biliary cirrhosis. Br Med J 1970; iii: 258-9.

3 Winkelmann R K. Carapeto F J, Jordon R E. Direct immunofluorescence in the diagnosis of scleroderma syndromes. $\mathrm{Br} J$ Dermatol 1977; 96: 231-8.

4 Heinzerling $\mathrm{R} \mathrm{H}$, Weyer R, Dziuba D S. Belviso $\mathrm{H} \mathrm{M}$, Gurnham T K. Elevated levels of antibodies to polyuric acid detected and quantitated in systemic scleroderma patients by solid phase radioimmunoassay. J Invest Dermatol 1980; 75: 224-7.

5 Norton W L, Nardo J M. Vascular disease in progressive systemic sclerosis. Ann Intern Med 1970; 73: 317-24.

6 Fleischmajer R, Damiano V, Nedwich A. Scleroderma and the subcutaneous tissue. Science 1971; 171: 1019-21.

7 Uitto J, Ohlenschlager K, Lorenzen I B. Solubility of skin collagen in normal human subjects and in patients with generalized scleroderma. Clin Chim Act 1971; 31: 13-8.

8 Fleischmajer R, Perlish J. Glycosaminoglycans in scleroderma and scleredema. J Invest Dermatol 1972; 58: 129-32.

9 Hardy K H, Rosevear J W, Sams W M, Winkelmann R K. Scleroderma and urinary excretion of acidic glycosaminoglycans. Mayo Clin Proc 1971; 46: 119-27.
10 Cabral A, Castor C W. Connective tissue activation. XXVII. The behavior of skin fibroblasts from patients with scleroderma. Arthritis Rheum 1983; 26: 1362-9.

11 Bashey R I, Millan A, Jiminez S A. Increased biosynthesis of glycosaminoglycans by scleroderma fibroblasts in culture. Arthritis Rheum 1984; 27: 1040-5.

12 Laurent U B G, Laurent T C. On the origin of hyaluronate in blood. Biochem Int 1981; 2: 195-9.

13 Fraser J R E, Laurent T C, Pertoft H, Baxter E. Plasma clearance, tissue distribution and metabolism of hyaluronic acid injected intravenously in the rabbit. Biochem $J$ 1981; 200: 415-24.

14 Fraser J R E. Laurent T C, Engström-Laurent A, Laurent U B G. Elimination of hyaluronic acid from the blood stream in the human. Clin Exp Pharmacol Physiol 1984; 11: 17-25.

15 Laurent U B G, Tengblad A. Determination of hyaluronate in biological samples by a specific radioassay technique. Anal Biochem 1980; 109: 386-94.

16 Laurent U B G. Hyaluronate in aqueous humour. Exp Eye Res 1981: 33: 147-55.

17 Dahl L, Hopwood J J. Laurent U B G, Lilja K. Tengblad A. The concentration of hyaluronate in amniotic fluid. Biochem Med 1983; 30: 280-3.

18 Engström-Laurent A. Laurent U B G, Lilja K, Laurent T C. Concentration of sodium hyaluronate in serum. Scand J Clin Lab Invest (in press).

19 Masi A T. Rodnan G P. Preliminary criteria for the classification of systemic sclerosis (scleroderma). Arthritis Rheum 1980; 23: $581-90$.

20 Sharp G C, Irwin W S. Tan E M. Gould R G, Holman H R. Mixed connective tissue disease; an apparently distinct rheumatic disease syndrome associated with a specific antibody to an extractable nuclear antigen (ENA). Am J Med 1972; 52: 148-59.

21 McKeehan W L, McKeehan K A. Hammond S L, Ham R G. Improved medium for clonal growth of human diploid fibroblasts at low concentrations of serum proteins. In Vitro 1977; 13:399-416.

22 McKeehan W L, Ham R G. Assay and partial purification of factors from serum that control multiplication of human diploid fibroblasts. Biochem Biophys Res Commun 1978; 80: 1013-21.

23 Johnsson A, Heldin C H, Westermark B, Wasteson $\AA$. Platelet derived growth factor: identification of constituent polypeptide chains. Biochem Biophys Res Commun 1982; 104: 66-8.

24 Antonas K N, Fraser J R E, Muirden K D. Distribution of biologically labelled radioactive hyaluronic acid injected into joints. Ann Rheum Dis 1973; 32: 103-11.

25 Engström-Laurent A. Hällgren R. Circulating hyaluronate in rheumatoid arthritis: relationship to inflammatory activity and the effect of corticosteroid therapy. Ann Rheum Dis 1985; 44: 83-8.

26 Yaron M, Yaron I, Wiletzki C, Zor U. Interrelationship between stimulation of prostaglandin $\mathrm{E}$ and hyaluronate production by poly (I), poly (C) and interferon in synovial fibroblast culture. Arthritis Rheum 1978; 21: 694-8.

27 Westermark B, Heldin C-H, Ek B, et al. Biochemistry and biology of platelet-derived growth factor. In: Guroff G, ed. Growth and maturation factors. New York: Wiley, 1983: 73-114.

28 Oka Y, Orth D N. Human plasma epidermal growth factor/ $\beta$-urogastrone is associated with blood platelets. J Clin Invest 1983; 72: 249-59.

29 Castor C W, Ritchie J C, Williams C H Jr, et al. Connective tissue activation. XIV. Composition and action of a human platelet autocoid mediator. Arthritis Rheum 1979; 22: 260-72.

30 Sisson J C, Castor C W, Klavons J A. Connective tissue activation. XVIII. Stimulation of hyaluronic acid synthetase activity. J Lab Clin Med 1980; 96: 189-97.

31 Moore S, Pepper D S, Cash J D. The isolation and characterisation of a platelet specific $\beta$-globulin ( $\beta$-thromboglobulin) and 
the detection of antiurokinase and antiplasmin from thrombinaggregated washed human platelets. Biochim Biophys Acta 1975; 379: 360-9.

32 Kahalek M B, Osborn I, Leroy E C. Elevated levels of circulating platelet aggregates and beta-thromboglobulin in scleroderma. Ann Intern Med 1982; 96: 610-3.

33 Kaplan K L, Broekman M J, Chernoff A, Lesznik G R, Drillings M. Platelet alpha-granule proteins: studies on release and subcellular localization. Blood 1979; 53: 604-9.

34 Fraser J R E, Appelgren L-E, Laurent T C. Tissue uptake of circulating hyaluronic acid. A whole body autoradiographic $\square$ study. Cell Tissue Res 1983; 233: 285-93.

35 Eriksson S, Fraser J R E, Laurent T C, Pertoft H, Smedsrød B. $\Rightarrow$ Endothelial cells are a site of uptake and degradation of hyaluronic acid in the liver. Exp Cell Res 1983; 144: 223-8.

36 Smedsrød B, Pertoft H, Eriksson S, Fraser J R E, Laurent T C. In vitro studies on the uptake and degradation of sodium hyaluronate in rat liver endothelial cells. Biochem $J$ (in press).

37 Engström-Laurent A, Nyberg A, Lööf L. Increased serum hyaluronate in liver diseases. Hepatology (in press). 